\title{
Tourist Motivation and Perception of Three Favorite Tourist Attractions in Kupang Regency
}

\author{
(Study on Baumata Pond, Tablolong Beach and Mount Fatuleu)
}

\author{
Agustino Lukas Fischer Conterius*, Rio Benedicto Bire, Asbi Nasar \\ Tourism Department \\ State Kupang Polytechnic \\ Kupang, Indonesia \\ *agustino.conterius@gmail.com
}

\begin{abstract}
The current research focuses on the motivation and perception of tourists towards the three favorite tourist attractions in Kupang Regency, namely the tourist attractions of the Baumata Pond, Tablolong Beach and Mount Fatuleu. This study aims at determining the motivation of tourists visiting, especially to Baumata Pond, Tablolong Beach and Mount Fatuleu, as well as to identify tourists' perceptions of attractions, amenities, accessibility, and ancillary services. This type of research is a descriptive study with a quantitative approach. To support this research, primary data and secondary data were used, with data collection techniques through observation, interviews, questionnaires, documentation and literature study. The sampling technique used in this study was accidental sampling with a total sample size, (1) Baumata pond with 99 respondents, (2) Tablolong Beach with 99 respondents, (3) Mount Fatuleu with 99 respondents. The findings of this study show that the average tourist has a very high motivation, which includes physical or physiological motivation, cultural motivation, social or interpersonal motivation and fantasy motivation to travel to the three favorite tourist attractions of Kupang Regency. The average tourist also has a very good perception of the $4 \mathrm{~A}$ components, which includes attractions, facilities, accessibility and ancillary services.
\end{abstract}

Keywords-motivation, perception, baumata pond, tablolong beach, mount fatuleu

\section{INTRODUCTION}

Tourism plays a significant role in economic growth of various countries. The tourism sector, if properly developed, can contribute to an increase in national income as well as potential regional income [1]. Growth of the tourism sector will create jobs for the population, reduce unemployment and deprivation, generate new business opportunities and add to the region's original income and raise national income [2].

Kupang Regency is one of the districts of East Nusa Tenggara Province that has begun to concentrate its attention on the growth of the tourism sector. There is a great deal of tourism potential in Kupang Regency, in the form of biodiversity, beautiful landscapes, charming beaches, historical heritage, the beauty and authenticity of traditional culture that can be optimally used for the well-being of the community. There are currently seven tourist attractions that are officially managed by the Kupang District Government and which have become a priority to be developed. The following are seven tourist attractions managed by the Kupang Regency Government along with the number of tourist visits in 2019.

TABLE I. TOURIST VISITS AND TOURIST ATTRACTIONS IN KUPANG REGENCY

\begin{tabular}{|l|l|l|l|}
\hline \multirow{2}{*}{ Tourist Attraction } & \multicolumn{3}{c|}{ Tourist Visits in 2019 } \\
\cline { 2 - 4 } & Foreigner & \multicolumn{1}{c|}{ Local } & \multicolumn{1}{c|}{ Total } \\
\hline Baumata Pond & - & 11.880 & 11.880 \\
\hline Oenesu Falls & 48 & 3.952 & 4.000 \\
\hline Tablolong Beach & 1.003 & 9.747 & 10.750 \\
\hline Manikin Beach & 41 & 3.659 & 3.700 \\
\hline Mount Fatuleu & 855 & 11.045 & 11.900 \\
\hline Tesbatan Waterfall & - & 900 & 900 \\
\hline Horse Racetrack & - & 1000 & 1.000 \\
\hline Total & 1.947 & 42.183 & 44.130 \\
\hline
\end{tabular}

Based on the data in Table 1 above, it is observed that there are three tourist attractions with more than 10.000 tourist visits, namely the Baumata Pond, Tablolong Beach and Mount Fatuleu tourist attractions. These three tourist attractions considered as the favorite places for people to visit in Kupang Regency, accordingly we find that these three tourist attractions can be used as a barometer for this study.

The development of a tourist attraction is closely related to the encouragement and understanding of tourists as the key consumers of tourism activities. Knowing the motivations of tourists as well as the opinions or perceptions of tourists about the attractions of the Baumata Pond, Tablolong Beach and Mount Fatuleu are considered imperative in order to improve its management in order to enhance tourist satisfaction. The main goal of the management of a tourist attraction is to provide tourists with satisfaction as consumers of tourism, in addition to the fact that each tourist generally has a diverse tourist motivation and specific opinions or assumptions about 
the attraction itself that needs to be taken into consideration in regards to tourism development in the future. Thus, studies in the related topic are contended.

The main objective of managing a tourist attraction is to provide and enhance satisfaction for tourists as users of tourism. Every tourist basically has different motivations and perceptions or assessments of preferred tourist attractions that has the potential to be developed in the future [3]. The development of a tourist attraction is closely related to the motivation and perception of visitors as the main consumers in tourism activities [4]. Knowing the tourist motivations and perceptions regarding the tourist attractions of Baumata Pond, Tablolong Beach and Mount Fatuleu, it is very important to provide as inputs and study material for the Kupang Regency Government as a basis for planning and formulating strategies in the development and management of its tourism attraction in Baumata, Tablolong Beach, and Mount Fatuleu in an effort to increase the number of tourist visits. The insights from measuring the motivation and perceptions of tourists can also be a reference for the development of potential tourist attractions that have not been developed by the Kupang Regency Government, considering that there is quite a lot of tourism potential in the district which would be a pity if not seized optimally.

The objectives of this research are: (1) to identify motivation of tourists in visiting three of Kupang Regency's favorite tourist attractions, and (2) to explore the tourist perceptions of attractions, facilities, accessibility and ancillary services at three of Kupang Regency's favorite tourist attractions. The motivation and perceptions of tourists are contended as critical as inputs for the Kupang District Government, in this case, the Kupang Regency Tourism and Creative Economy Office as a basis for planning and managing tourist attractions and for formulating policies and strategies to increase the number of tourist visits.

\section{LITERATURE REVIEW}

Tourism encompasses a wide range of tourism activities and is supported by facilities and services offered by the community, businesses, and the government [5]. The tourism sector currently plays a critical role as a driving force in promoting the development and enhancement of the economy of a region or country if properly managed and developed. Tourism is a very strategic asset to be enhanced in growth in those regions that have the potential to attract tourist visits [6].

The presence of tourist attractions is an important part of tourism. Travel attractions are all things that have uniqueness, beauty and value in the form of a diversity of natural resources, culture and human-made products that attract the tourists to visit [7]. Accordingly, the local government is obliged to explore and develop its tourist attraction so that it can become one of the potential sources of income for improving the people's well-being.

Tourists who come to visit a tourist attraction will take part in consumption activities and spend a large amount of money, ranging from transport to the purchase of goods/services in the geographical area where the tourist attraction is located, such as accommodation, food and drinks, souvenirs and recreational services. Consumption activities carried out by tourists will contribute to the improvement of the tourism industry and the business activities operated by the community, increase of people's income, jobs, and the reduction of unemployment, as well as to the government's income from the tax sector. With the development of the tourism sector, economy will be enhanced. On the other hand, filing to seize opportunities for tourism development will lead to possible stagnant growth.

The creation of tourist attractions should be tailored to the needs and desires of visitors. Tourists are defined as the people who travel [8]. At the same time, tourism is a travel activity carried out by a person or a group of people by visiting a particular place for leisure, personal development or by discovering the significance of a tourist attraction visited in a temporary period of time [9]. Responding to the needs and desires of tourists who are engaged in absolute tourism activities is required in aim to satisfy tourists by their experience when visiting a tourist attraction. Accordingly, it is envisioned for longer length of stays and repeated visits by the tourists [10].

In visiting a tourist attraction, generally a tourist has a certain motivation in carrying out their activities. Motivation is a desire within an individual that stimulates someone to do a certain action. The higher the motivation of a person, the higher the effort made to achieve what is desired [11]. Basically, a person who takes a tour is generally motivated by several factors. The motivations can be grouped into four major groups, namely: (1) physical or physiological motivation, which is related to relaxation, health, comfort, participate in sports activities, leisure and so on, (2) cultural motivation, namely the desire to know the culture, customs, traditions and arts of other people, including the interest in various cultural heritage objects, (3) social or interpersonal motivation, which is the motivation in relation to other human beings, such as visiting friends and family, meeting work partners, doing things that are considered to bring prestige (prestige), pilgrimage, and escaping from routine activities, and (4) fantasy motivation, namely the desire for a certain setting where an individual may temporarily "exit" their daily routine which provides psychological satisfaction [12]. If the motivation of these tourists can be fulfilled when conducting tourism activities, they will be satisfied and will likely return to visit the same attraction in the future.

In addition to motivation, tourists' perceptions of a tourist attraction contribute to the satisfaction or dissatisfaction towards the attraction along with its service components experienced by tourists during their visit. Perception is an element of cognition that will determine travel satisfaction. Satisfaction towards tourist attraction is strongly influenced by the quality of services obtained in the tourist destination [13]. Moreover, tourist perception is an impression that is manifested in the form of interpretation and attitude towards tourism attractiveness, tourism facilities, public facilities, 
tourism information and services provided to visitors while in the tourist attraction [14].

In conducting tourism activities, a tourist will usually give a perception on the " $4 \mathrm{~A}$ " components contained in a tourist attraction which includes: (1) attractions, which are tourist objects that are in a place or area, (2) amenities, which are facilities that support tourism activities in tourist destinations, (3) accessibility, which refers to the ease of movement or access for tourists, ranging from ease of access to tourist attractions to ease of the search for tourist attractions, and (4) ancillary service, which is a service that supports tourism activities, such as the existence of a tourism awareness group or private institution to manage tourism development in a tourist destination, the existence of a tourist information centre that provides information to tourists in the form of brochures, books, maps and competent tour guides [14]. The quality of 4A components is instrumental to return visits.

\section{RESEARCH METHODS}

This research was conducted in three of the seven tourist attractions operated by the Kupang Regency Government with the highest number of tourist visits, namely the Baumata Pond, Tablolong Beach and Mount Fatuleu. The tourism motivation used in this analysis is physical or physiological motivation, cultural motivation, social or interpersonal motivation, and fantasy motivation. The perception used in this study is the perception of tourists as measured by the 4A components, namely attractions, facilities, accessibility and ancillary services.

This method of study used is empirical analysis with a quantitative approach; a process of seeking knowledge that uses data in the form of numbers as a way of collecting information on what a tourist wants to know [15]. To support this work, primary and secondary data collection methods have been gathered through observation, interviews, questionnaires, reports and literature studies.

The test instruments used in this study were validity and reliability tests to measure whether the questionnaire used in this study was valid or not and to ensure that the questionnaire used in this study could provide consistent, comprehensive and reliable data or information [16]. In this study, the authors distributed questionnaires consisting of four tourist motivation indicators with sixteen statement items and four tourist perception indicators with twenty statement items to the respondents of this study.

The population in this study is visitors who visited the attractions of Baumata Pond, Tablolong Beach and Mount Fatuleu. The sampling method used in this analysis is accidental sampling. In order to assess the number of test samples, we used the Slovin formula with an error tolerance of $10 \%$ and obtained as many samples of tourists as possible (1) Baumata Pond as 99 respondents, (2) Tablolong Beach as 99 respondents, (3) Mount Fatuleu as 99 respondents.
For evaluating the attitudes of visitors, the Likert scale is employed. Data obtained is analysed and tabulated. Results are presented in form of tables, and are further descriptively explained. The following criteria are used to define the percentage of responses and the collected indicator values [17].

- 0 percent-20 percent $=$ strongly dissatisfied $/$ very bad / very low

- 21 percent -40 percent $=$ dissatisfied $/$ not good $/$ low

- 41 percent-60 percent $=$ OK / Good enough / High enough

- 61 percent -80 percent $=$ OK $/ \operatorname{good} /$ high

- 81 per cent -100 per cent $=$ very good / very strong

\section{RESULTS AND DISCUSSION}

There are 16 statements from four indicators of tourist motivation to visit three of Kupang Regency's favorite tourist attractions, namely the Baumata Bay, Tablolong Beach and Mount Fatuleu. Results are presented in Table II to Table V.

TABLE II. Results For Physical or Physiological Motivation

\begin{tabular}{|l|l|l|l|}
\hline \multicolumn{1}{|c|}{ Indicator } & $\begin{array}{c}\text { Baumata } \\
\text { Pond } \\
(\boldsymbol{\%})\end{array}$ & $\begin{array}{c}\text { Tablolong } \\
\text { Beach } \\
(\boldsymbol{\%})\end{array}$ & $\begin{array}{c}\text { Mount } \\
\text { Fatuleu } \\
(\boldsymbol{\%})\end{array}$ \\
\hline $\begin{array}{l}\text { Physical or Physiological } \\
\text { Motivation }\end{array}$ & 81,9 & 86,04 & 85,38 \\
\hline 1. Relaxation & 85,03 & 89,68 & 86,65 \\
\hline 2. Comfort & 75,73 & 87,66 & 84,83 \\
\hline 3. Health & 83,01 & 76,74 & 84,43 \\
\hline 4. Relax & 83,83 & 90,08 & 85,64 \\
\hline
\end{tabular}

Regarding the physical or physiological motivation indicator as presented in Table II, the average values point to a very high rating from tourists when visiting Baumata Pond (81.9 per cent), Tablolong Beach (86.04 per cent) and Mount Fatuleu ( 85.38 per cent). This indicates that tourists have a very strong physical or physiological incentive for leisure and relaxation activities, finding warmth, relaxation and other health-promoting activities when travelling to the three favorite tourist attractions of Kupang Regency.

TABLE III. RESUlts FOR CULTURAL MOtIVATION

\begin{tabular}{|l|l|l|l|}
\hline \multicolumn{1}{|c|}{ Indicator } & $\begin{array}{c}\text { Baumata } \\
\text { Pond } \\
(\mathbf{\%})\end{array}$ & $\begin{array}{c}\text { Tablolong } \\
\text { Beach } \\
(\mathbf{\%})\end{array}$ & $\begin{array}{c}\text { Mount } \\
\text { Fatuleu } \\
(\mathbf{\%})\end{array}$ \\
\hline Cultural Motivation & $\mathbf{6 8 , 1 5}$ & $\mathbf{7 3 , 3 7}$ & $\mathbf{7 2 , 1}$ \\
\hline $\begin{array}{l}\text { 1. Knowing the habits of the } \\
\text { surrounding community }\end{array}$ & 67,46 & 74,13 & 72,3 \\
\hline $\begin{array}{l}\text { 2. Seeing the way of life of the } \\
\text { surrounding community }\end{array}$ & 67,25 & 73,72 & 72,31 \\
\hline $\begin{array}{l}\text { 3. Seeing the art of the } \\
\text { surrounding community }\end{array}$ & 68,46 & 72,71 & 71,49 \\
\hline $\begin{array}{l}\text { 4. Knowing the traditions of the } \\
\text { surrounding community }\end{array}$ & 69,46 & 72,92 & 72,3 \\
\hline
\end{tabular}


On the achievement of the second motivation indicator, which is cultural motivation as presented in Table III, the average value points to a high rating among tourists when visiting Baumata Pond (68.15\%), Tablolong Beach (73.37\%), and Mount Fatuleu (72.1\%). This suggests that, in addition to physical or physiological motivation, tourists also have cultural motivation in travelling to these three tourist attractions, to see how the habits and ways of life of the people around the tourist attraction of Baumata Pond, Tablolong Beach, and Mount Fatuleu.

TABLE IV. RESULTS FOR SOCIAL OR INTERPERSONAL MOTIVATION

\begin{tabular}{|l|l|l|l|}
\hline \multicolumn{1}{|c|}{ Indicator } & $\begin{array}{c}\text { Baumata } \\
\text { Pond } \\
(\mathbf{\%})\end{array}$ & $\begin{array}{c}\text { Tablolong } \\
\text { Beach } \\
\mathbf{( \% )}\end{array}$ & $\begin{array}{c}\text { Mount } \\
\text { Fatuleu } \\
(\mathbf{\%})\end{array}$ \\
\hline $\begin{array}{l}\text { Social or Interpersonal } \\
\text { Motivation }\end{array}$ & $\mathbf{7 8 , 2 1}$ & $\mathbf{8 0 , 8 4}$ & $\mathbf{8 2 , 3 0}$ \\
\hline $\begin{array}{l}\text { 1. Spending time with your } \\
\text { spouse, family, relatives or } \\
\text { friends }\end{array}$ & 86,24 & 88,87 & 86,65 \\
\hline $\begin{array}{l}\text { 2. Strengthen relationships } \\
\text { with partners, family, } \\
\text { relatives or friends }\end{array}$ & 83,41 & 86,25 & 85,24 \\
\hline $\begin{array}{l}\text { 3. Meet and interact socially } \\
\text { with many people }\end{array}$ & 84,02 & 82,61 & 83.82 \\
\hline $\begin{array}{l}\text { 4. Increase prestige and } \\
\text { reputation among family, } \\
\text { relatives or friends }\end{array}$ & 59,17 & 65,64 & 73,52 \\
\hline
\end{tabular}

In regards to the third motivation measure as displayed in Table IV, visitors have a strong social or interpersonal incentive to travel to the Baumata Pond (78.21 per cent) and Tablolong Beach (80.84 per cent). The highest rating was found for those visiting Mount Fatuleu (82.30 per cent). A relatively low rating was found for Baumata Pond in terms of increase prestige and reputation among family, relatives or friends $(59,17)$, however on average, tourists are concluded to have fulfilled their social needs, especially in regards to relations with spouses, families, relatives and friends, which can foster and improve the relationship among them.

TABLE V. RESULTS FOR FANTASY MOTIVATION

\begin{tabular}{|l|l|l|l|}
\hline \multicolumn{1}{|c|}{ Indicator } & $\begin{array}{c}\text { Baumata } \\
\text { Pond } \\
(\mathbf{\%})\end{array}$ & $\begin{array}{c}\text { Tablolong } \\
\text { Beach } \\
(\mathbf{\%})\end{array}$ & $\begin{array}{c}\text { Mount } \\
\text { Fatuleu } \\
(\mathbf{\%})\end{array}$ \\
\hline Fantasy Motivation & $\mathbf{7 7 , 3 7}$ & $\mathbf{8 7 , 7 5}$ & $\mathbf{8 6 , 6 4}$ \\
\hline 1. Getting own satisfaction & 83,82 & 88,86 & 86,45 \\
\hline $\begin{array}{l}\text { 2.Wanting to enjoy the } \\
\text { beautiful natural panorama } \\
\text { and is different from other } \\
\text { tourist attractions }\end{array}$ & 73,93 & 87,46 & 87,65 \\
\hline $\begin{array}{l}\text { 3. Taking pictures in the } \\
\text { exotic photo spots / spots and } \\
\text { upload them on social media } \\
\text { accounts }\end{array}$ & 74,73 & 89,45 & 87,25 \\
\hline $\begin{array}{l}\text { 4. Becoming a person who is } \\
\text { ree from all burdens of mind }\end{array}$ & 77,14 & 85,24 & 85,24 \\
\hline
\end{tabular}

As displayed in Table $\mathrm{V}$, the fourth motivation indicator, namely the fantasy motivation, presents a high rating among tourists when visiting Baumata Pond (77.37 per cent) and very high ratings for visiting Tablolong Beach ( 87.75 per cent) and Mount Fatuleu (86.64 per cent). This indicates that tourists believe that travelling in the Baumata Bay, Tablolong Beach and Mount Fatuleu will satisfy the fantasy desire to pursue personal experience and happiness, free up all the pressures in their minds by relaxing, taking pictures, and enjoying the beautiful natural scenery.

There are twenty statements from four indicators of the tourist perceptions variable measured for the three favorite tourist attractions in Kupang Regency. Results of the analysis is presented in Table VI to Table IX.

TABLE VI. RESUlTS FOR TOURIST PERCEPTION OF ATTRACTION

\begin{tabular}{|l|l|l|l|}
\hline \multicolumn{1}{|c|}{ Indicator } & $\begin{array}{c}\text { Baumata } \\
\text { Pond } \\
(\boldsymbol{\%})\end{array}$ & $\begin{array}{c}\text { Tablolong } \\
\text { Beach } \\
(\mathbf{\%})\end{array}$ & $\begin{array}{c}\text { Mount } \\
\text { Fatuleu } \\
(\%)\end{array}$ \\
\hline Attraction natural & $\mathbf{7 7 , 5 1}$ & $\mathbf{8 5 , 7 6}$ & $\mathbf{8 6 , 4 0}$ \\
\hline $\begin{array}{l}\text { 1. Beautiful } \\
\text { panorama }\end{array}$ & 72,71 & 92,1 & 89,27 \\
\hline $\begin{array}{l}\text { 2. The atmosphere is cool, } \\
\text { beautiful and pleasant }\end{array}$ & 84,42 & 86,65 & 88,67 \\
\hline $\begin{array}{l}\text { 3. Clean, comfortable and } \\
\text { free of rubbish }\end{array}$ & 75,74 & 77,16 & 82,41 \\
\hline $\begin{array}{l}\text { 4. Having an interesting } \\
\text { spot to take pictures }\end{array}$ & 73,71 & 90,29 & 88,26 \\
\hline $\begin{array}{l}\text { 5. Safe and free from } \\
\text { crime }\end{array}$ & 80,99 & 82,61 & 83,42 \\
\hline
\end{tabular}

From the results in Table VI, the first perception indicator which is attraction obtained a very high assessment of indicators among tourists visiting Tablolong Beach (85.76 per cent) and Mount Fatuleu (86.40 per cent), while a moderate rating (77.51 per cent) was found for the attractions in Baumata Pond. This suggests that tourists believe these three tourist attractions do possess superior natural scenery, cool, peaceful, good, healthy, garbage-free, interesting spots or locations to take pictures among these three attractions. Moreover, the results indicate that these tourist attractions are safe from criminal conduct

TABLE VII. RESULTS FOR TOURISTS PERCEPTION OF AMENITIES

\begin{tabular}{|l|l|l|l|}
\hline \multicolumn{1}{|c|}{ Indicator } & $\begin{array}{c}\text { Baumata } \\
\text { Pond } \\
(\mathbf{\%})\end{array}$ & $\begin{array}{c}\text { Tablolong } \\
\text { Beach } \\
(\mathbf{\%})\end{array}$ & $\begin{array}{c}\text { Mount } \\
\text { Fatuleu } \\
(\mathbf{\%})\end{array}$ \\
\hline Amenities & $\mathbf{7 5 , 8 6}$ & $\mathbf{7 8 , 3 2}$ & $\mathbf{7 9 , 3 4}$ \\
\hline $\begin{array}{l}\text { 1. Adequate and clean } \\
\text { dressing room / bathroom } \\
\text { (toilet) }\end{array}$ & 75,52 & 73,51 & 76,34 \\
\hline $\begin{array}{l}\text { 2. Adequate and safe } \\
\text { parking area }\end{array}$ & 72,91 & 78,16 & 81,2 \\
\hline $\begin{array}{l}\text { 3. Adequate trash can } \\
\text { facilities }\end{array}$ & 76,95 & 78,15 & 80,99 \\
\hline $\begin{array}{l}\text { 4. Adequate and clean } \\
\text { gazebo or lopo facilities }\end{array}$ & 77,75 & 84,84 & 79,58 \\
\hline $\begin{array}{l}\text { 5.Places to sell food and } \\
\text { drinks that are adequate } \\
\text { and clean }\end{array}$ & 79,17 & 76,95 & 78,57 \\
\hline \multicolumn{2}{|l|}{} & & \\
\hline
\end{tabular}


As presented in Table VII, the second perception indicator which is amenity, shows, a high rating for Baumata Pond (75.86\%), Tablolong Beach $(78.32 \%)$ and Mount Fatuleu (79.34\%). This indicates that tourists perceive that these three tourist attractions present adequate amenities to support tourist activities.

TABLE VIII. RESULTS FOR TOURISTS PERCEPTION OF ACCESSIBILITY

\begin{tabular}{|l|l|l|l|}
\hline \multicolumn{1}{|c|}{ Indicator } & $\begin{array}{c}\text { Baumata } \\
\text { Pond } \\
(\mathbf{\%})\end{array}$ & $\begin{array}{c}\text { Tablolong } \\
\text { Beach } \\
(\mathbf{\%})\end{array}$ & $\begin{array}{c}\text { Mount } \\
\text { Fatuleu } \\
(\%)\end{array}$ \\
\hline Accessibility & $\mathbf{8 0 , 8 3}$ & $\mathbf{7 1 , 5 3}$ & $\mathbf{7 9 , 6 9}$ \\
\hline $\begin{array}{l}\text { 1.The quality of roads that } \\
\text { are well maintained }\end{array}$ & 79,78 & 63,82 & 82 \\
\hline 2. Easy to reach location & 85,23 & 72,31 & 82,6 \\
\hline $\begin{array}{l}\text { 3.There are modes of public } \\
\text { transportation }\end{array}$ & 74,73 & 56,14 & 69,68 \\
\hline 4. There is a signpost & 76,96 & 78,16 & 78,77 \\
\hline $\begin{array}{l}\text { 5.Location information that } \\
\text { can be accessed through } \\
\text { internet media }\end{array}$ & 87,46 & 87,25 & 85,44 \\
\hline
\end{tabular}

In regards to the third perception indicator which is accessibility as displayed in Table VIII, a high rating is found for Baumata Pond (80.83\%), Tablolong Beach $(71.53 \%)$ and Mount Fatuleu $(79.69 \%)$. This suggests that tourists perceive an adequate access towards the three attractions.

TABLE IX. RESUlts For TOURIST PERCEPTION ON ANCILlary SERVICE

\begin{tabular}{|l|l|l|l|}
\hline \multicolumn{1}{|c|}{ Indicator } & $\begin{array}{c}\text { Baumata } \\
\text { Pond } \\
(\mathbf{\%})\end{array}$ & $\begin{array}{c}\text { Tablolong } \\
\text { Beach } \\
(\%)\end{array}$ & $\begin{array}{c}\text { Mount } \\
\text { Fatuleu } \\
(\mathbf{\%})\end{array}$ \\
\hline Ancillary Service & $\mathbf{7 2 , 0 6}$ & $\mathbf{7 4 , 7 3}$ & $\mathbf{8 0 , 1 0}$ \\
\hline $\begin{array}{l}\text { 1. Managing staff are always } \\
\text { friendly to tourists }\end{array}$ & 78,97 & 76,15 & 81,6 \\
\hline $\begin{array}{l}\text { 2. The management officer } \\
\text { provides complete tourist } \\
\text { attraction information }\end{array}$ & 75,33 & 73,11 & 79,58 \\
\hline $\begin{array}{l}\text { 3. The management officer } \\
\text { ensures tourist safety }\end{array}$ & 76,14 & 73,51 & 79,17 \\
\hline $\begin{array}{l}\text { 4. The availability of } \\
\text { promotional media and } \\
\text { tourist attraction information } \\
\text { through social media }\end{array}$ & 67,46 & 79,58 & 82,81 \\
\hline $\begin{array}{l}\text { 5. The availability of } \\
\text { promotional media and } \\
\text { tourist attraction information } \\
\text { through print media }\end{array}$ & 87,46 & 87,25 & 85,44 \\
\hline
\end{tabular}

Results from the fourth perception measure which is ancillary service as displayed in Table IX reports a high assessment for the Baumata Pond (72.06 per cent), Tablolong Beach (74.73 per cent) and Mount Fatuleu (80.10 per cent). Such results mean that tourists believe that the ancillary of the three favorite tourist attractions in the Kupang district is satisfactory.

The results of this research that have been presented are in line with Pitana and Diarta [12] who regard that physical or physiological, cultural, social or interpersonal, and fantasy motivation are components that drives tourists to visit tourist attractions. The results of this study also show that tourists 'perceptions of attractions, amenities, accessibility, and ancillary services contained in a tourist attraction are important elements that can influence tourists' decisions to visit a tourist attraction [14] and further, these 4 components are proven to influence tourist decision to visit the tourist attractions of Baumata Pond, Tablolong Beach and Mount Fatuleu.

Results from this study are also in line with that of Keliwar and Nurcahyo [3] which states that physical or physiological, cultural, social or interpersonal, and fantasy motivation, as well as tourist perceptions of attractions, amenities, accessibility, and ancillary services are supporting factors in encouraging tourist visiting interest at Pampang Cultural Village in Samarinda. Moreover, our results are in terms with Angela et al. [4] which states that the motivation and perceptions of tourists which include attractions, amenities, accessibility, and ancillary services are very important roles in encouraging the interest of tourist visits to the tourist attraction of Jembong in Buleleng Regency.

\section{CONCLUSION}

The results of this study indicate a very high tourist motivation factor which includes (1) physical or physiological motivation in terms of recreation and relaxation, seeking comfort, relaxing and other activities in support of his health, (2) cultural motivation in terms of observing habits and ways of life of people (3) social or interpersonal motivation in regards to fulfilling the social needs in relation with spouses, family, relatives and friends and (4) fantasy motivation in terms of seeking personal experience and satisfaction, freeing all burdens of the mind to relax, take pictures and to enjoy the beautiful natural panorama. We conclude that the motivational indicator can be fulfilled when visiting the tourist attractions of Baumata Pond, Tablolong Beach, and Mount Fatuleu.

Results also point to good perceptions of the 4A components of the Baumata Pond, Tablolong Beach and Mount Fatuleu tourist attractions which include (1) attractions, consisting of beautiful natural panoramas, cool, beautiful, pleasant, clean, free from rubbish, interesting spots / locations for photos, (2) amenities, consisting of clean and adequate changing rooms and toilets, adequate and safe parking areas, adequate garbage facilities, adequate gazebo or shelter facilities and clean and adequate and clean places to sell food and drinks, (3) accessibility, consisting of quality of roads that are well maintained, locations that are easily accessible, modes of public transportation, road signposts as well as information on tourist attraction locations that can be accessed through internet media, and (4) ancillary service, which consists of tourist management officers who are always friendly, able to provide complete information, assurance of safety for tourists, and adequate promotional media about tourist attractions through social and mass media.

Based on the findings of this study, the Kupang District Government through the Kupang Regency Tourism and 
Creative Economy Agency must be able to maintain and even improve the quality of attractions, amenities, accessibility and ancillary services found in the tourist attractions of Baumata Pond, Tablolong Beach, and Mount Fatuleu. In addition, the measurement of tourist motivation and perception can serve as inputs for the Kupang Regency Government as a basis for planning and formulating strategies in developing and managing tourist attractions as an effort to increase the number of tourist visits on tourist attractions managed by the Kupang Regency Government. Furthermore, our findings can be used as a reference for the development of potential tourist attractions that have not been developed by the Kupang Regency Government, given that there are quite a lot of tourism potential in the regency.

Lastly, our findings may serve as a basis of reference for further researchers to conduct deeper empirical studies within a similar theme related to the motivation and perceptions of tourists towards a tourist attraction by adding research variables, indicators, as well as extending the study period, and comparing the tourist attractions analyzed in this study with that of other tourist attractions in order to obtain more reliable results.

\section{REFERENCES}

[1] A.J. Muljadi and A. Warman, Tourism and Travel. Jakarta: Raja Grafindo, 2012.
[2] O.A. Yoeti, Tourism Economics. Jakarta: Kompas, 2008.

[3] S. Keliwar and A. Nurcahyo, "Visitor Motivation and Perception of the Attraction of Pampang Cultural Village in Samarinda," Journal of Resort and Leisure Management, vol. 12, no. 2, pp. 10-27, 2015.

[4] M.M. Angela, M.N.O. Karini, and M.N.S. Wijaya, "Visitor Motivation and Perception of the Attraction of Jembong in Jembong District," Travel Industry Journal, vol. 5, no. 2, pp. 76-91, 2017.

[5] Law Number 10 Year 2009 Concerning Tourism Article 1 Paragraph 3.

[6] H. Aryunda, "The Economic Impact of the Development of the Thousand Islands Ecotourism Area," Journal of Regional and City Planning, vol. 22, no. 1, pp. 1-16, 2011.

[7] Law Number 10 of 2009 concerning Tourism Article 1 Paragraph 5.

[8] Law Number 10 of 2009 concerning Tourism Article 1 Paragraph 2.

[9] Law Number 10 of 2009 concerning Tourism Article 1 Paragraph 1

[10] H.C. Murti, “Tourist Perception of Botang Dolphin Center Tourism Object Development," Journal Earth of Indonesia, vol. 2, no. 2, pp. 260267, 2013.

[11] Sedarmayanti, Human Resource Management. Bandung: PT. Refika Aditama, 2016.

[12] I.G. Pitana and I.K.S. Diarta, Introduction to Tourism Science. Yogyakarta: ANDI, 2009.

[13] S. Nasution, M.A. Nasution, and J. Damanik, "Perception of Foreign Tourists on the Quality of Objects and Tourist Attractions of North Sumatra," Journal of Development Studies, vo. 1, no. 1, pp. 81-96, 2005.

[14] M.L. Suryadana and V. Octavia, Introduction to Tourism Marketing. Bandung: ALFABETA, 2015.

[15] M. Kasiram, Research Methodology. Malang: UIN-Malang Pers, 2008.

[16] Sugiyono, Management Research Methods. Bandung: Alfabeta., 2015.

[17] Riduwan, Basic Statistics. Bandung: ALFABETA, 2015. 